\title{
Urazy szczęk i twarzy w doświadczeniu chirurgicznym Dominika Jeana Larreya
}

\begin{abstract}
Injuries to jaw and face in surgical experience Dominique Jean Larrey

Summary

Reconstructive surgery has a long way to go. In Europe, Dominique Jean Larrey surgeon, humanist and innovator wrote a very interesting card in this area. In addition to practical actions often taken on the battlefields of the Napoleonic era, he devoted a significant part of his scientific achievements to the problems of maxillofacial surgery, also educating his students in this direction. And here is a handful of messages from over two hundred years ago.
\end{abstract}

Słowa kluczowe: chirurgia szczękowo-twarzowa, Dominique Jean Larrey, wojny napoleońskie

Keywords: Maxillo-facial surgery, Dominique Jean Larrey, Napoleonic wars

W czasie pracy nad biografią Dominika Jeana Larreya ${ }^{1}$ trudno było nie zapoznać się w sposób dogłębny z jego bogatą spuścizną naukową. Dzieła o takim charakterze rządzą się swoimi prawami, a jednocześnie cały szereg prezentowanych przez Larreya tematów, nowatorskich podówczas, a w chwili obecnej już z lekka zapomnianych działań, wręcz domagało się swojego dodatkowego omówienia i pogłębionego opracowania. Jednym z nich są właśnie prezentowane urazy

${ }^{1}$ M.J. Turos, Dominique Jean Larrey (1766-1842), Oświęcim 2017. 
szczęk i twarzy, którym poświęcił dużo miejsca w swoich tekstach, przede wszystkim w wielotomowych Memoires $^{2}$, a także Clinique chirurgicale $^{3}$, jak również innych, mniejszych opracowaniach ${ }^{4}$. Zapisy te, o wybitnie dokumentacyjnym charakterze, były efektem skutecznych metod praktycznych, jakie podejmował, często bezpośrednio na polu walki, ratując życie i zdrowie wielu żołnierzy.

Twarz ludzka od wieków stanowiła symbol piękna, będąc odbiciem Istoty Najwyższej5. Lecz jednocześnie było to piękno niezwykle kruche, które łatwo mogło ulec deformacji bądź zniszczeniu na skutek urazu, choroby lub też kary. Tę ostatnią stosowano we wszystkich kulturach, a za wyjątkowo hańbiące, na terenie Europy, Bliskiego i Środkowego Wschodu, uważano obcięcie nosa i uszu, a także wypalenie piętna na policzku bądź na czole ${ }^{6}$. Przekłucie czy raczej przecięcie uszu zgodnie z przekazem biblijnym oznaczało wieczne niewolnictwo ${ }^{7}$. Nic więc dziwnego, że równolegle starano się usuwać skutki tego rodzaju okaleczeń. W krajach Azji, a szczególnie w Indiach, takie zabiegi rekonstrukcyjne wykonywane były już ok. VI w. p.n.e. Wskazuja na to zachowane fragmenty traktatu Susruta Samhita ${ }^{8}$, którego autorstwo wiąże się z imieniem indyjskiego lekarza Sushruty ${ }^{9}$, a przede wszystkim zamieszczone $\mathrm{w}$ tekście ryciny przedstawiające kolejne fazy wykonywania zabiegu odtwórczego w obrębie nosa.

O naukowych początkach chirurgii obrażeń twarzy na terenie Europy, po próbach podejmowanych w starożytności przez Celsusa i Galena ${ }^{10}$, można mówić w związku z funkcjonowaniem szkoły medycznej funkcjonującej w Salerno na Sycylii, lecz, o czym wspomina David Hamilton, działania te po początkowych sukcesach zostały w średniowiecznej Europie prawie zupełnie zapomniane ${ }^{11}$. Jednak

${ }^{2}$ D.J. Larrey, Memoires de chirurgie et de campagnes, t. I-III, Paris 1812; D.J. Larrey, Memoires de chirurgie militaire et campagnes, t. IV, Paris 1817.

${ }^{3}$ D.J. Larrey, Clinique chirurgicale, exercée particulièrement dans les camps et les hôpitaux militaires, depuis 1792 jusqu'en 1829, t. I, II, III, Paris 1829; T. IV, Paris 1832; T. V, Paris 1836.

${ }^{4}$ D.J. Larrey, Relation médicale de campagnes et voyages de 1815 à 1840, Paris 1841.

${ }^{5}$ A. Znosko, Mały słownik wyrazów starocerkiewnosłowiańskich i terminologii cerkiewno-liturgicznej, Warszawa 1983, s. 165.

${ }^{6}$ I. Dziekońska, Kara, Warszawa 1963, s. 63-65.

7 II Mojż. 26.6. Tu za: „Biblija Święta”, Londyn 1945.

${ }^{8}$ S. Saraf, R. Parihar, Sushruta: The first Plastic Surgeon in 600 B.C., „The Internet Journal of Plastic Surgery" 2006, Vol. 4, No. 2.

9 V. Singh, Sushruta: The father of surgery, „National Journ. of Maxillofac Surg” 2017, Jan-Jun, No. 8(1), s. 1-3.

10 D. Hamilton, A History of Organ Transplantation: Ancient Legends to Modern Practice, Pittsburgh 2012, s. 13.

11 Tamże, s. 16-17. 
wprowadzenie od połowy XV w. na pola bitew ręcznej broni palnej12 oraz narastająca brutalizacja walk sprawiły, że liczba tego typu urazów zaczęła lawinowo wzrastać. Ich okaleczające skutki mogły stanowić jedną z przyczyn, dla których ówcześni chirurdzy zaczęli się znów zajmować działaniami odtwórczymi. Do tekstów powstałych w szkole salernitańskiej powrócił wykładowca z Padwy Alessandro Benedetti w swoim dziele Anatomice sive historia corporis humani ${ }^{13}$ wydanym w 1514 r. i przypuszczalnie na tej podstawie Gaspare Tagliacozzi opracował technikę rekonstrukcji nosa, którą, wraz z odpowiednimi szczegółowymi rycinami, zaprezentował w traktacie De Curtorum Chirurgia per Insitionem Libri Duo ${ }^{14}$ wydanym w Wenecji, na trzy lata przed jego śmiercią, w 1597 r. Temat ten interesował również wybitnego chirurga francuskiego owych czasów, którym był Ambroise Pare ${ }^{15}$.

Liczba ciężkich urazów twarzy jeszcze bardziej wzrosła na przełomie XVIII i XIX w., kiedy na polach bitew już wyraźnie dominowała coraz doskonalsza technicznie broń palna o dużej sile rażenia, powodująca znaczne uszkodzenia ciała. Stąd trudno, by zagadnienie pomocy $\mathrm{w}$ takich sytuacjach nie zainteresowało jednego $\mathrm{z}$ najwybitniejszych chirurgów francuskich owego okresu, którym był Dominique Jean Larrey. Stykał się z takimi obrażeniami i poświęcał im dużo uwagi, poczynając od pierwszych walk armii republikańskiej toczonych nad Renem w 1792 r., szczególnie w czasie bitew stoczonych pod Phalsbourgiem i pod Spirą ${ }^{16}$.

Warto w tym miejscu zaznaczyć, że ranni w twarz i głowę, ze względu na bardzo niepewne rokowania odnośnie do wyleczenia, na ogół nie byli opatrywani i często nawet nie zabierano ich z pobojowiska ${ }^{17}$. Ten wyjątkowo niehumanitarny zwyczaj zwalczał w swojej Chirurgii

12 M. Mackiewicz, Średniowieczna ręczna broń palna, http://www.muzeumwp.pl/ emwpaedia/sredniowieczna-reczna-bron-palna.php [dostęp: 12.06.2019].

13 „Alexandri Benedicti physici Anatomice sive historia corporis humani euisdem collectiones medicinales seu aforismi" in Officina Henrici Stephani, Parisiis 1514.

${ }^{14}$ Gasparis Taliacotii ... De curtorum chirurgia per insitionem, libri duo: in quibus ea omnia, quae ad huius chirurgiae, narium scilicet, aurium, ac labiorum per insitionem restaurandorum cum thoricen, tum practicen pertinere videbantur, clarissima methodo cumulatissimè declarantur ; additis cutis traducis instrumentorum omnium, atque deligationum iconibus, \& tabulis. Cum indice quadruplici expeditissimo, capitum singulorum, authorum, controuersiarum, rerum denique \& verborum memorabilium, Ad Gasparem Bindonium Juniorem, Venetiis 1597.

${ }_{15}$ J.T. Shen, M. Weinstein, Ambroise Pare (1510 to 1590): A Surgeon Centuries Ahead of His Time, „The American Surgeon”, June 2014, No. 80, s. 538.

${ }^{16}$ A.L., Notice biographique sur la vie et sur les travaux de M. le Baron Larrey, Paris 1841, s. 4.

${ }_{17}$ F.X. Long, Les blessés de la face durant la Grande Guerre. Les origines de la chirurgie maxillo-faciale, „Hist. des Sciences Medic.” 2002, t. XXXVI, nr 2, s. 176. 
praktycznej, dziele przez wiele lat funkcjonującym w rękopisie, ojciec chirurgii polskiej Rafał Józef Czerwiakowski ${ }^{18}$. Zagadnieniom postępowania w tego typu obrażeniach poświęcił w niej kolejne sześć paragrafów ${ }^{19}$, w których omawiał m.in. sposoby zbliżania brzegów niewielkich ran za pomocą specjalnych, dopasowanych kształtem, lepkich plastrów, oraz zakładanie szwów wszędzie tam, gdzie doszło do głębszego urazu tkanek. Zwracał także uwagę na staranne wykonywanie opatrunków tej okolicy anatomicznej, wyróżniając w innym ze swoich dzieł, zatytułowanym Narzadu opatrzenia chirurgicznego, blisko 56 rodzajów „opasek” ${ }^{20}$, gdyż tym mianem określał bandaże, przeznaczonych m.in. do zaopatrzenia ran okolic oczu, warg, nosa, szczęki oraz brody. Zaprezentował je również w oddzielnym atlasie opublikowanym w 1817 r. i kończącym wydaną rok wcześniej monografię, gdzie sposobom wykonywania opatrunków poświęcił plansze opatrzone kolejnymi numerami XIX, XX, XXI XXII oraz część XXIII ${ }^{21}$, co stanowi ponad połowę części poświęconej stronie technicznej samego nakładania opasek.

Podobnie i Larrey pochylał się nad każdym poszkodowanym żołnierzem. Pierwszą rzeczą, na jaką zwracał uwagę, było zachowanie maksymalnej czystości rany, zatamowanie krwawienia przez pierwszy opatrunek o charakterze uciskowym ze specjalnie zwiniętych pasemek szarpi i później, w jak najkrótszym czasie, właściwy szew skórny. W celu ułatwienia postępowania skonstruował trzy rodzaje igieł, zakończonych niewielkimi płaskimi grocikami, przeznaczonych do szycia ran w obrębie szyi i twarzy. Pozwalały one na dokładne zbliżenie brzegów rany przy jednoczesnym zachowaniu maksymalnego kształtu np. przeciętych warg, uszu czy powieki, a jednocześnie nie powodowały dużego dodatkowego uszkodzenia skóry, przez co można je uznać za prototyp późniejszych tnących igieł atraumatycznych. Wprowadził też podział rozmiarów i kształtów używanych przez siebie igieł na duże, średnie, małe i bardzo malutkie oraz proste, półkoliste, a także kształtu mniej okrągłego ${ }^{22}$, i następnie powiązał te parametry instrumentów z okolicą anatomiczną, w jakiej dany szew

\footnotetext{
${ }^{18}$ E. Grzelak (red.), Chirurgia praktyczna Rafała Józefa Czerwiakowskiego, Warszawa 1969, s. 60.

19 Tamże, s. 253-260.

${ }^{20}$ R.J. Czerwiakowski, Narzadu opatrzenia chirurgicznego, Część II $\$ 196$ - \$743, w Krakowie 1816 roku, s. 173-232.

${ }^{21}$ Narzadu powszechnego opatrzenia chirurgicznego część VII tabele, przez Rafała Jóżefa Czerwiakowskiego, Kraków 1817.

${ }_{22}$ D.J. Larrey, Memoires de chirurgie..., dz. cyt., t. I, s. 62.
} 
miał być zakładany. Działania podejmowane w tym zakresie przyniosły mu złoty medal Academie de Chirurgie w Paryżu „o wartości 100 liwrów wręczony podczas posiedzenia publicznego"23, które odbyło się 11 kwietnia $1793 \mathrm{r}$. W czasie jego trwania wygłosił ponadto swój referat poświęcony koncepcji szybkiej pomocy rannym na polu walki. Generalnie tak mówił o swoich pierwszych doświadczeniach: „szew założony natychmiast pozwala bardzo łatwo zbliżyć krawędzie rany, zwłaszcza na obszarze twarzy, a tym samym ogranicza późniejsze deformacje" 24 . Wers ten tradycja łączy z przemową po otrzymaniu nagrody, choć, o czym wspomina w swojej pracy Xavier Riaud, pełny tekst wystąpienia nie zachował się ${ }^{25}$. Larrey zwracał również uwagę na szybkość narastania obrzęku po tego typu dużych urazach, który w pewnym stopniu mogły ograniczać okłady z zimnej wody z octem lub roztworem soli. W pewnych sytuacjach stosował również specjalny sposób zespolenia, pozostawiając $\mathrm{w}$ tkankach cienkie proste igły i wokół nich zakładając pętelki z nici w formie ósemki, co wzmacniało go, szczególnie w tych miejscach, gdzie rana była głęboka, a jej brzegi trudne do zbliżenia. Ten rodzaj szwu, o którym wspomina również Czerwiakowski, nosił nazwę szwu okręcanego ${ }^{26}$ bądź też tzw. wargi zajęczej27.

Według opinii Karine Ferret-Dussart ${ }^{28}$ działania podejmowane przez Larreya, niejednokrotnie $\mathrm{w}$ bardzo trudnych warunkach polowych, były postępowaniem ze wszech miar właściwym. Zabiegi, jakie przeprowadzał, pod względem sposobu ich wykonania w niczym nie odbiegają od techniki stosowanej współcześnie w chirurgii szczękowo-twarzowej. Pomimo całego szeregu ograniczeń, przede wszystkim braku znieczulenia, dokonywał plastyki nosa, już w czasie szycia rany zakładając m.in. sondę, która pozwalała kształtować przecięte nozdrza, wykonywał również cały szereg zabiegów wewnątrzustnych, nie tylko zakładając szwy, ale także mocując rozchwiane zęby specjalnymi pętelkami z plecionego, cienkiego, srebrnego drutu. Podobnie stosowanie przez niego prototypów szyn z metalowych drutów, unieruchamiających szczękę czy żuchwę oraz opatrunków stabilizujących można uznać za

${ }^{23}$ J. Marchioni, Place a monsieur Larrey, Arles 2006, s. 51.

${ }^{24} \mathrm{X}$. Riaud, Chirurgie maxillo-faciale et Grande Armée, ,e-mémoires de l'Académie Nationale de Chirurgie" 2016, nr 15(4), s. 54.

${ }^{25}$ Tamże.

${ }^{26}$ R.J. Czerwiakowski, Narzadu powszechnego opatrzenia chirurgicznego, cz. IV, w Krakowie 1816, s. 212.

27 Tamże.

${ }^{28} \mathrm{~K}$. Ferret-Dussart, La chirurgie maxillo-faciale à travers l'histoire, Paris 2004, s. 104-109. 
ciekawe i na owe czasy nowatorskie. Pewne techniki chirurgii plastycznej w obrębie twarzy, a szczególnie posługiwanie się przemieszczonymi płatami skórnymi, również zasługują na upamiętnienie.

Prócz działań typowo praktycznych Dominique Jean Larrey, choć w opinii niektórych historyków był przede wszystkim specjalistą od niezwykle szybko przeprowadzanych amputacji ${ }^{29}$, zajmował się również stroną, jeśli tak można rzec, naukową i dydaktyczną dotyczącą obrażeń twarzy i z dużym talentem prezentował zdobyte w tym zakresie doświadczenie. W każdej ze swoich prac poświęcał omawianemu zagadnieniu wiele miejsca, stąd warto zapoznać się z nimi. Najlepiej jest to uczynić $\mathrm{w}$ układzie chronologicznym, czyli uwzględniając kolejne pozycje $\mathrm{z}$ jego dorobku, $\mathrm{w}$ miarę jak ukazywały się $\mathrm{w}$ druku:

1. Relation historique et chirurgicale de l'expedition de l'armee d'Orient en Egypte et en Syrie ${ }^{30}$

Jest to pierwsza z jego obszerniejszych monografii przygotowana w latach 1801-1802. O problemach urazów twarzy pisze w rozdziale VIII, określanym przez niego mianem „sekcja”, w którym znaleźć można dwa akapity, pierwszy zatytułowany Rany głowy wraz z obserwacjami $^{31}$ i drugi, zdecydowanie bardziej szczegółowy, Rany twarzy $i$ gardła $^{32}$, gdzie już w pierwszym wersie nawiązuje do swojej wypowiedzi z paryskiego wystąpienia w 1793 r.: „rany gdzie doszło do uszkodzenia tkanek miękkich okolic ust zostały wyleczone przez założenie natychmiastowego szwu, przy czym nie było późniejszych zniekształceń"33. W dalszym ciągu tekstu omawia kolejno trzy przypadki, które operował, i którymi opiekował się aż do wyleczenia pacjentów.

Jednym z nich był Louis Vaute, kapral 88 demi-brigade, który został ciężko ranny w twarz podczas oblężenia Aleksandrii. Kula uszkodziła szczękę dolną i doprowadziła do dużego ubytku skóry sięgającego aż do szyi. Po usunięciu martwych tkanek Larrey opatrzył ranę i po 35 dniach od chwili zranienia przygotował do ewakuacji do Francji.

2. Memoires de chirurgie et campagnes ${ }^{34}$

Dzieło to, powstałe w latach 1810-1816, składa się z czterech tomów, z których trzy pierwsze ukazały się drukiem w 1812 r. W pierw-

${ }^{29}$ Tu m.in. R. Bielecki, Encyklopedia wojen napoleońskich, Warszawa 2002, s. 351.

${ }^{30}$ Relation historique et chirurgicale de l'expedition de l'armee d'Orient en Egypte et en Syrie par D. J. Larrey, Paris 1.An XI (1803).

${ }^{31}$ Tamże, s. 280-282.

32 Tamże, s. 283-289.

${ }_{33}$ Tamże.

${ }^{34}$ Tamże. 
szym, obejmującym prócz zapisów z wyprawy na Nową Fundlandię również działania armii Renu, znaleźć można obszerne teoretyczne oraz praktyczne uwagi dotyczące nowych igieł do szycia ran twarzy ${ }^{35}$, a także doboru nici odpowiednich do miejsca zranienia, które musiały być stosunkowo cienkie, jednocześnie sprężyste i dodatkowo jeszcze w minimalnym stopniu drażniące skórę oraz błonę śluzową. Wszystkie te zalety miał jedwab specjalnie nasączany woskiem. Akapit ten przypuszczalnie powstał na bazie notatek bądź też jest fragmentem wspomnianego już wystąpienia z $1793 \mathrm{r}$.

Ciekawą rzeczą jest też przyczynek - co prawda niedotyczący bezpośrednio działań chirurgicznych - o zmianach chorobowych błony śluzowej jamy ustnej ${ }^{36}$, które mogą wystąpić jako skutki działania całego szeregu czynników zewnętrznych, takich jak zimno, małowartościowe pożywienie oraz zanieczyszczenia warg, przede wszystkim prochem. Tu warto wspomnieć, że żołnierze w trakcie nabijania broni musieli przegryzać zębami papierowy nabój i dopiero później wsypywać jego zawartość wraz z kulą do lufy karabinu, mieli więc przede wszystkim kontakt z siarką oraz saletrą wchodzącą w skład prochu, ale także z mikrocząsteczkami ołowiu.

$\mathrm{W}$ tomie drugim, gros uwagi autora skupione zostało na kampanii egipskiej w VIII sekcji (w ten sposób Dominique Jean Larrey wyodrębniał większe partie tekstu, o czym już było wspomniane uprzednio) znaleźć można samodzielny rozdział zatytułowany Chirurgia ${ }^{37}$. W nim kolejno przedstawione zostały dwa mniejsze, szczegółowe podrozdziały. Pierwszy z nich poświęcony został urazom czaszki i połączony $\mathrm{z}$ opisem przeprowadzonych podówczas zabiegów operacyjnych oraz obserwacjami stanu pacjentów ${ }^{38}$, natomiast drugi, noszący podtytuł Urazy twarzy i gardta ${ }^{39}$, dotyczył ran tych okolic. Jako istotny czynnik wpływający na odległe wyniki postępowania, a przede wszystkim brak bądź niewielkie późniejsze deformacje, Larrey uznał znów jak najszybsze i najdokładniejsze zeszycie rany. Omówił przy tym bardziej szczegółowo dwa przypadki. Pierwszy dotyczył adiutanta generała Verdiera, któremu kula pistoletowa rozerwała lewy policzek, język i częściowo wargi: „po oczyszczeniu rany i usunięciu najbardziej zniszczonych fragmentów mięśni zbliżyłem jej brzegi przez założenie dziewięciu specjalnych szwów odwracanych, kuracja bez gwałtownej

\footnotetext{
35 D.J. Larrey, Memoires..., dz. cyt., t. I, s. 61-64.

36 Tamże, s. 86-89.

37 Tamże, t. II, s. 130-194

38 Tamże, s. 136-139.

39 Tamże, s. 140-149.
} 
gorączki i innych problemów trwała siedemnaście dni, zaś sama deformacja była niewielka” ${ }^{40}$. Jak sam nadmienia, „podobny przypadek zdarzył się już w mojej praktyce, gdy byłem w armii Renu"41, w przypisie zaś wspomina, że w czasie zabiegu wykorzystał igły własnej konstrukcji, które zostały omówione już uprzednio. Drugi natomiast to rozwinięcie historii choroby wzmiankowanego już Louisa Vautego, gdzie z rzeczy ciekawszych warto zacytować fakt, iż przez cały czas kuracji w Aleksandrii był karmiony przez sondę wprowadzoną do żołądka, czyli „podawano mu bulion i po kilka łyżek dobrego wina, co trzy godziny" ${ }^{42}$. Pacjent po ewakuacji początkowo przebywał w Louvain, a następnie znalazł się w Hôtel des Invalides w Paryżu i „mówił całkiem dobrze, zaś część ubytku i blizn została zakryta maską ze srebra" 43 .

W dalszej części tekstu zaprezentowane zostały jeszcze trzy inne przypadki rozległych urazów twarzy - w tym usunięcie ciała obcego, fragmentu ostrza bagnetu długości ok. $3 \mathrm{~cm}$, wbitego w podniebienie, który od sześciu tygodni tkwił w tkankach, uniemożliwiając normalne mówienie i odżywianie się poszkodowanego ${ }^{44}$. Ich leczenie również przebiegało pomyślnie.

Tom trzeci, obejmujący lata 1806-1810, również zawiera akapit poświęcony ranom głowy i twarzy ${ }^{45}$. Nie jest on, co prawda, wyodrębniony w samym tekście, ale został wyraźnie zaznaczony w spisie treści. Tutaj gros uwagi autora skupione zostało na urazach czaszki, lecz znaleźć też w nim można interesujący przyczynek dotyczący obrażeń twarzy. Nie ma go, co prawda, bezpośrednio w tekście opublikowanym drukiem w 1812 r., lecz został opracowany przez Justina Godarta ${ }^{46}$. Przeanalizował on dokładnie dopiski Larreya, które były przez niego prowadzone na marginesach oraz luźnych kartkach włożonych pomiędzy stronice, często połączone z korektą. Znajdowały się one praktycznie we wszystkich tomach pierwszego wydania Memoires przekazanego przez syna Hipolita do zbiorów biblioteki Szkoły Medycznej Val-de-Grâce w Paryżu. Ofiarodawca zaznaczył w akcie darowizny, że egzemplarz z nanoszonymi do treści licznymi uwagami

\footnotetext{
${ }^{40}$ Tamże, s. 144.

41 Tamże.

42 Tamże, s. 142.

43 Tamże, s. 143.

${ }^{44}$ Tamże, s. 144.

45 D.J. Larrey, Memoires et campagnes..., dz. cyt., t. III, s. 310-331.

46 J. Godart, Quelques notes inedites du Baron Larrey, „Le Progres Medical”, nr 9-10 (20 Mars 1940), s. 174.
} 
zawsze znajdowały się na stole, przy którym jego ojciec pisał i czytał $^{47}$. Wyniki pracy Justina Godarta dołączono do pełnego wydania krytycznego pierwszej części dzieł Larreya, obejmujących Memoires et campagnes oraz Relation médicale de campagnes et voyages de 1815 à 1840, które ukazało się drukiem w 2004 r. ${ }^{48}$

Owo interesujące zdarzenie miało miejsce po bitwie pod Czarnowem stoczonej nocą z 23 na 24 grudnia 1806 r. Larrey, obchodząc swoim zwyczajem pobojowisko, znalazł rannego szeregowca, któremu rosyjska szabla przecięła twarz, uszkadzając nos i policzek, na szczęście nie naruszając kości. Doniósł go do ambulansu urządzonego w kościele w Pomiechowie, po czym operował. Sam zabieg, podczas którego zwrócił uwagę na wpływ zimna - padał deszcz ze śniegiem na wygląd rany oraz związane z tym możliwości działania, jak również dalsza kuracja przebiegły pomyślnie, a jedynym śladem pozostała tylko „bardzo długa blizna oraz trochę gorsze odczucie zapachu w lewej dziurce nosa" ${ }^{49}$. Historię tę, co prawda utrzymaną w konwencji lekko legendarnej, podaje również Marco de Saint-Hilaire ${ }^{50}$.

W samym tekście można znaleźć jeszcze przypadek pułkownika Jeannina, rannego w bitwie pod Heilsbergiem (Lidzbark Warmiński). Pocisk kartaczowy trafił go w twarz, łamiąc lewą żuchwę oraz masakrując policzek. Larrey po dokładnym oczyszczeniu rany założył - jak sam pisze - „dwanaście szwów i plastry” ${ }^{51}$. Polecił nie dotykać ich przez okres do pięciu dni, po czym wraz z innymi rannymi ewakuował swojego pacjenta do Torunia. Jak stwierdził później z nieukrywaną satysfakcją, rana zagoiła się, nie zostawiając dużej deformacji, której się obawiał.

W tym miejscu należy zaznaczyć, że wielu chirurgów armii napoleońskiej, pomimo obiekcji odnośnie do postępowania z rannymi w twarz, podejmowało się ich leczenia, przeprowadzając mniej i bardziej skomplikowane zabiegi operacyjne. Christophe Bourachot wymienia tu, niestety nie podając imion, m.in. takich lekarzy, jak dr Cuynat i dr Eve ${ }^{52}$, którzy opiekowali się rannymi żołnierzami w niezwykle trudnym okresie kampanii moskiewskiej, a szczególnie podczas odwrotu. Jednym z nich był porucznik Danel, ranny w bitwie pod Win-

\footnotetext{
47 Tamże, s. 173.

${ }^{48}$ D.J. Larrey, Memoires et campagnes, Wydanie krytyczne, Paris 2004.

49 Tamże, s. 472.

${ }^{50}$ M. de Saint-Hilaire, Historia Napoleona, Gdańsk 2004, s. 205-206.

${ }^{51}$ D.J. Larrey, Memoires et campagnes..., dz. cyt., t. III, s. 81.

${ }^{52}$ Ch. Bourachot, Les hommes de Napoléon - Témoignages (1805-1815), Paris 2011, wprowadzenie, b.p.
} 
kowem 18 października 1812 r., któremu kula pistoletowa wystrzelona z bliskiej odległości rozerwała prawy policzek i podniebienie ${ }^{53}$. Wypada tu wspomnieć również François Girardota, chirurga polskiego pułku szwoleżerów gwardii. Jego działania, również prowadzone bezpośrednio na polu bitwy, wspominał jeden $\mathrm{z}$ oficerów tej formacji, porucznik Wincenty Płaczkowski. Podczas walk pod Ciudad Rodrigo doszło do zranienia angielskiego oficera: ,z jednej strony twarzy cały policzek był odcięty [...] Wnet zawołano doktora Żerarda (Girardot), który go zaraz opatrzył i policzek mu przyhaftował [...] Ten oficer był szefem batalionu grenadierów szkockich" 54 .

Podobny przypadek zdarzył się również pod Benavente, gdzie Larrey zeszył francuskiemu kawalerzyście głęboką ranę policzka i powieki, zakładając, o czym sam szczegółowo pisze: „siedem odpowiednich szwów i opatrunek, który sam zmieniłem po siedmiu dniach"55.

Czwarty tom Memoires, który, o czym już było wspomniane, powstał w całości w 1816 r., czyli po zakończeniu wojen napoleońskich, i został opublikowany $\mathrm{w}$ roku następnym ${ }^{56}$, zawiera $\mathrm{w}$ części drugiej poświęconej kampanii 1813 r. na terenie Saksonii dość obszerny, liczący 37 stron, rozdział noszący dość długi tytuł Réflexions sur les plaies de tête avec fracture des os du crâne, présence de corps étrangers; et sur la cause des abcès au foie à la suite de ces plaies ${ }^{57}$ (Refleksje na temat ran głowy połaczonych z pęknięciem kości czaszki, obecnościa ciat obcych i o ropniach watroby będacych skutkiem tych zranień), gdzie kolejno zostały wyodrębnione akapity poświęcone pojedynczym obrażeniom twarzy ${ }^{58}$, następnie ranom ust i okolic jamy ustnej ${ }^{59}$ oraz ranom gardła ${ }^{60}$.

Kampania rosyjska, gdyż ona jest tematem pierwszej części ${ }^{61}$, przysporzyła całego szeregu urazów twarzy. Jeden z nich, dotyczący oficera rosyjskiego operowanego 26 lipca 1812 r., został opisany przez Larreya z wyjątkowymi szczegółami. „Pułkownik rosyjski został cięty przez francuskiego kawalerzystę. Szabla przecięła mu nos przez całą długość i ciągnęła się aż do wargi dolnej [...] usunąłem skrzepy

\footnotetext{
53 Tamże.

${ }^{54}$ W. Płaczkowski, Pamiętniki porucznika dawnej gwardii cesarsko-francuskiej spisane $w$ roku 1845, Żytomierz 1861, s. 139-140.

55 D.J. Larrey, Clinique chirurgicale, exercée particulièrement dans les camps et les hôpitaux militaires, depuis 1792 jusqu'en 1829, T. II, Paris 1829, s. 5.

${ }^{56}$ D.J. Larrey, Memoires de chirurgie..., dz. cyt., t. IV.

57 Tamże, t. IV, s. 179-249.

58 Tamże, s. 210-214.

59 Tamże, s. 240-244.

${ }^{60}$ Tamże, s. 245-247.

${ }^{61}$ Tamże, s. 1-153.
} 
krwi i kurz pokrywający ranę [...] odpowiednio złożyłem nos i wargę górną, łącząc je wypróbowanym szwem, poczynając od nasady nosa, schodząc stopniowo do brzegów, te połączyłem 10 szwami. Ranę pokryłem przewiewnym kawałkiem płótna namoczonym w słonej wodzie. W nozdrza wprowadziłem dwie dość grube sondy z elastycznej gumy w celu zachowania jego kształtu i umocowałem je specjalnymi grubszymi nićmi [...] całość zakończył odpowiedni opatrunek, [...] gdy wróciłem z Moskwy, dowiedziałem się, iż ten wyższy oficer wrócił całkowicie do zdrowia i nie miał poważnych deformacji”"62.

Jest rzeczą ciekawą, że jeden z takich zabiegów został utrwalony na obrazie, którego autorem jest Louis François Lejeune, zatytułowanym „Bitwa pod Moskwą”, a powstałym w $1822 \mathrm{r}^{63}$ i znajdującym się obecnie $\mathrm{w}$ muzeum $\mathrm{w}$ Wersalu ${ }^{64}$. W dolnej części tej dużej kompozycji znaleźć można scenę, która rozegrała się wczesnym popołudniem podczas tej trwającej kilkanaście godzin batalii. Przedstawiony na pierwszym planie Larrey, od kwietnia 1812 r. naczelny chirurg Wielkiej Armii, opatruje generała Charles'a Moranda, rannego kulą karabinową w dolną część twarzy, gdy prowadził atak dywizji piechoty korpusu marszałka Louisa Davouta. I jest to owa słynna „kotlinka"65, o której ów wybitny chirurg wspomina z sarkazmem, iż tam właśnie mógł znaleźć jedyne w miarę spokojne miejsce, by urządzić przynajmniej prowizoryczny ambulans i spieszyć z pomocą rannym, gdzie nie było wody i tym bardziej szans na rozstawienie namiotu czy nawet pozostawienie furgonu. A cóż zanotował o samej interwencji chirurgicznej przeprowadzonej w tak nietypowym miejscu? „Została uszkodzona dolna szczęka i policzek aż do podbródka [...] usunąłem pojedyncze fragmenty kostne i założyłem cały szereg szwów, starając się przywrócić normalny wygląd twarzy, a później całość unieruchomiłem" ${ }^{66}$. Generał Charles Morand przez wiele tygodni odwrotu mógł porozumiewać się jedynie za pomocą gestó ${ }^{67}$, a rozległa rana pomimo ciężkich warunków została wyleczona pomyślnie, pozostawiając jedynie nieznaczną deformację.

${ }^{62}$ Tamże, s. 20-22.

${ }^{63}$ J. Benoît, La bataille de la Moskova par le général baron Lejeune, „Revue du Souvenir Napoléonien", décembre 2004, nr 455-6, s. 45-54.

${ }^{64}$ Réunion des Musées Nationaux, Grand Palais (Château de Versailles).

${ }^{65}$ R.D. Richardson, Larrey: Surgeon to Napoleon's Imperial Guard, London 1974, S. 160

${ }^{66}$ D.J. Larrey, Relation médicale de..., dz. cyt., s. 369.

${ }^{67}$ M. Allégret, Morand Charles Antoine Louis Alexis (1771-1835), général, comte d'Empire, „Revue du souvenir napoléonien” (décembre 2005-janvier 2006), nr 462, s. $75-76$. 
W późniejszych latach, już po upadku cesarza Napoleona, powstały kolejne prace Larreya:

1. Recueil de memoires de chirurgie ${ }^{68}$

Jest to uzupełnienie do czterech tomów uprzednio wydanych Memoires, i praktycznie jedyne $\mathrm{z}$ obszerniejszych dzieł, w którym autor wyjątkowo nie porusza problemów związanymi z urazami szczęk i twarzy.

2. Clinique chirurgicale, exercée particulièrement dans les camps et les hôpitaux militaires, depuis 1792 jusqu'en $1829^{69}$

Zasadnicze spośród dzieł naukowych Larreya, liczące pięć tomów tekstu oraz szósty, choć opisany, jako atlas tomu piątego ${ }^{70}$, zawierający ryciny. Kolejno ukazywały się one w latach 1829-1836.

W drugim tomie znaleźć można obszerny, liczący 64 strony $^{71}$ rozdział zatytułowany Rany twarzy, poświęcony bezpośrednim obrażeniom oraz innym schorzeniom tej okolicy anatomicznej, i jest to bez wątpienia największy samodzielny tekst, jaki wyszedł spod pióra tego wybitnego chirurga. Kolejne akapity dotyczą:

1) ran prowadzących do zniszczenia nosa,

2) refleksji na temat zabiegów odtwórczych - rynoplastyki.

Nie są one wyszczególnione nagłówkami bezpośrednio w tekście, ale za to wyraźnie wyodrębnione w spisie treści. Na szczególną uwage zasługuje tu przypadek pacjenta skierowanego do szpitala Gros Caillou przez dr. Zinka, dawnego asystenta Larreya. Był to podoficer, który w czasie próby samobójczej strzelił sobie w usta z karabinu, naciskając spust stopą. Doszło do rozległego zniszczenia tkanek podniebienia, szczęki górnej między kłami oraz nosa. Rany częściowo zagoiły się, pozostawiając deformację i ogromne, odstręczające okaleczenie.

Dominique Jean Larrey w asyście swojego asystenta dr. François Ribesa podjął się operacji. A oto jej szczegółowy przebieg sporządzony najprawdopodobniej tuż po przeprowadzonym zabiegu: ,posadziwszy pacjenta na krześle zacząłem od uruchomienia skóry wokół rany, aby uzyskać wystarczająco duży płat i zacząłem okrywać nim ubytek [...] następnie przeciąłem zrosty w okolicy, gdzie kiedyś był nos i wargi, a potem tam, gdzie było podniebienie [...] to stanowiło najtrudniejszą część operacji, odświeżyłem krawędzie ostrymi nożyczkami i uformowałem zaczątek nosa [...] po umyciu i osuszeniu założyłem trzy prowizoryczne szwy przede wszystkim w miejscu, gdzie była

${ }^{68}$ D.J. Larrey, Recueil de memoires de chirurgie, Paris 1821.

${ }^{69}$ D.J. Larrey, Clinique chirurgicale, exercée..., dz. cyt., t. I-V.

${ }^{70}$ D.J. Larrey, Clinique chirurgicale, exercée particulièrement dans les camps et les hôpitaux militaires, depuis 1792 jusqu'en 1829. Atlas du tome cinquieme, br. m. i r. wyd.

${ }^{71}$ Tamże, t. II, s. 1-64. 
warga górna, następnie przy pomocy pętelek z drutu przybliżyłem płaty skórne, używając do tego igieł mojego pomysłu, a uformowaną wargę zeszyłem szwem odwracanym umocowanym do dwóch złotych igieł [...] założyłem opatrunek, którego zadaniem było wspieranie szwów"72. Po 9 dniach wszystkie tkanki połączone szwami zaczęły się zabliźniać, a po 15 , po ich usunięciu, rany były prawie zagojone i jak zaznaczył Larrey ku swej wielkiej radości - „na twarzy zostały tylko blizny, lecz nie było nic przerażającego dla oczu, mowa i żucie pokarmów zaś znacznie się poprawiły"73. Pacjent żył jeszcze kilka lat i zmarł z powodu udaru.

Według oficjalnych danych był to pierwszy zabieg rynoplastyki przeprowadzony przez Larreya, co do którego dysponujemy szczegółową dokumentacją, ale nie można wykluczyć, że techniki tej nie stosował już wcześniej. Zwracają na to uwagę m.in. Paul Tessier ${ }^{74}$ oraz Xavier Riaud ${ }^{75}$, poddając analizie przypadki, które chirurg ten prezentował przed omawianym powyżej pacjentem który został przedstawiony 22 lutego 1821 r. podczas posiedzeń naukowego Fakultetu Medycyny w Paryżu ${ }^{76}$, odwołując się niejednokrotnie do swoich doświadczeń wojennych.

Dominique Jean Larrey w swojej praktyce chirurgicznej powrócił do opisanej jeszcze przez Celsusa, a później przez wzmiankowanego już Gaspare'a Tagliacozziego metody postępowania w przypadkach rozległych zranień twarzy pozwalającej na rekonstrukcję dużych ubytków odpowiednio przesuwanymi płatami skóry. Stosował przy tym technikę, którą, jak się dość powszechnie przyjmuje i o czym pisał m.in. Jules Rochard ${ }^{77}$, wznowił dopiero wiele lat później niemiecki chirurg Johann Friedrich Dieffenbach, korzystając przy tym najprawdopodobniej z tekstów zgłoszonych przez Larreya i wydanych w zbiorze prac, które zostały opublikowane przez Faculte de Medecine w Paryżu.

${ }^{72}$ Tamże, s. 14-16.

${ }^{73}$ Tamże, s. 18.

${ }_{74} \mathrm{P}$. Tessier, Chirurgie réparatrice et morphologique du nez, „Revue du Practicien” 1958, Oct 21, nr 8 (27), s. 3085-3086 oraz P. Tessier, Rhinoplastie post-traumatique et rhinopoïèse, „Gaz Med Fr.” 1966 Fevrier, nr 10, 73(3), s. 499-536.

${ }_{75}$ X. Riaud, Maxillofacial Surgery and Napoleonic Great Army, „Oral Health Care” 2018, vol. 3(2), s. 3.

${ }^{76}$ Tamże.

$77 \mathrm{~J}$. Rochard, Histoire de la chirurgie francaise au xixe siècle: Etude historique et critique sur les progres faits en chirurgie et dans les sciences qui s'y rapportent, depuis las suppression de l'Academie royale de chirurgie jusqu'a l'époque actuelle, Paris 1875, s. 233. 
Prócz omówionego powyżej w tekst wplecionych jest jeszcze sześć innych obserwacji, poczynając od wzmiankowanej już w Memoires, a dotyczącej zranienia adiutanta gen. Verdiera, a kończąc na przypadku żołnierza rannego w twarz przez nieuwagę zimą 1815 r., u którego doszło również do oparzenia powiek prochem. Po oczyszczeniu rany powoli zagoiły się, nie zostawiając większych śladów.

Następne, już oznaczone tytułami rozdziały zawarte w drugim tomie, a dotyczące prezentowanego zagadnienia, dotyczą kolejno:

3) urazów penetrujących do zatoki szczękowej,

4) złamań szczęki i żuchwy,

5) zabiegów na języku, gdzie powraca jeszcze raz do sposobu wykonywania szwów przy użyciu specjalnych igieł,

6) torbieli podjęzykowych zwanych żabkami,

7) przetok ślinowych,

8) wyłuszczania migdałków podniebiennych.

W każdym z rozdziałów można znaleźć w zakończeniu kilka omówionych szczegółowo obserwacji zaczerpniętych z praktyki, m.in. wzmiankowanego już pułkownika Jeannina. Większość z tych analiz kazuistycznych stanowiła też tematykę wystąpień przygotowywanych przez Larreya na posiedzenia Academie Royale de Medecine. Tak było m.in. 24 kwietnia 1825 r., kiedy prezentował zagadnienia związane ze złamaniem żuchwy ${ }^{78}$.

W czwartym tomie również można znaleźć, co prawda krótki, fragment dotyczący obrażeń twarzy, w którym Larrey pisze o zabiegach operacyjnych, które przeprowadzał w szpitalu Gros Caillou w Paryżu w czasie walk w lipcu $1830 \mathrm{r}^{79}$ Został on usytuowany w większym, bardziej szczegółowym akapicie zatytułowanym Rany głowy - obserwacje ${ }^{80}$.

Po raz kolejny Larrey obszernie powraca do tej problematyki $\mathrm{w}$ ostatnim tomie, gdzie w liczącym 117 stron rozdziale opatrzonym tytułem Paragraf 1. Skutki urazów głowy oraz operacje praktykowa$n e w$ różnych okolicach anatomicznych ${ }^{81}$ znaleźć można dwa oddzielne, mniejsze podrozdziały, a mianowicie Rany twarzy ${ }^{82}$ obejmujący

${ }^{78}$ D.J. Larrey, Clinique chirurgicale, exercée..., dz. cyt., t. II, s. 38.

79 D.J. Larrey, Clinique chirurgicale, exercée particulièrement dans les camps et les hôpitaux militaires, depuis 1792 jusqu'en 1829, Ed. J-B. Balliere, T. IV, Paris 1832, s. 251, 289.

${ }^{80}$ Tamże, s. 261-266.

${ }^{81}$ D.J. Larrey, Clinique chirurgicale, exercée particulièrement dans les camps et les hôpitaux militaires, depuis 1792 jusqu'en 1829, Ed. J-B. Balliere, T. V, Paris 1836, s. 1.

${ }^{82}$ Tamże, s. 91-104. 
13 stron oraz Rany szczę $k^{83}$, potraktowany jako oddzielny temat i liczący również 13 stron.

Poruszając obydwa te tematy, jak zawsze nawiązuje do doświadczeń z wojen, szczególnie kampanii napoleońskich, prezentując przy tym obserwacje, często trwające wiele lat, jak przykładowo Louisa Dienne, mającego 55 lat, rannego w twarz w czasie odwrotu spod Moskwy, u którego doszło do przecięcia części policzka, nosa i powieki. Siła uderzenia uszkodziła także lewą gałkę oczną. Tu również po upływie dłuższego czasu od urazu i po częściowym zagojeniu się rany została przeprowadzona operacja rekonstrukcyjna, a „poza blizną, jedynym śladem pozostał brak widzenia w lewym oku, opisywany przez chorego jako zdolność widzenia światła"84.

Drugie z zagadnień zostało potraktowane zdecydowanie mniej szczegółowo, a wynika to przede wszystkim z faktu, iż obszerny, liczący blisko 65 stron tekst dotyczący budowy, schorzeń i urazów tej okolicy anatomicznej znaleźć można było w Dictionnaire des sciences médicales ${ }^{85}$, i to do niego Larrey często się odwoływał. Przygotował go do druku François Ribes, on zaś z szacunkiem odniósł się do pracy swojego ucznia, sugerując mu, na co wskazują zamieszczone ryciny oraz opisy przypadków, wykorzystanie własnych doświadczeń z kampanii hiszpańskiej. Wypada uznać to za bardzo interesujący przyczynek do kontaktów naukowych, jakie panowały w pierwszym dwudziestoleciu XIX w. w środowisku chirurgów uprzednio związanych z Wielką Armią.

Ostatnim tekstem, który wyszedł spod pióra Larreya, jest Relation médicale de campagnes et voyages de 1815 à $1840^{86}$, opublikowany na niecały rok przed śmiercią autora. Temat urazów twarzy nie jest w niej bliżej poruszany, za to w kończącym tom zestawieniu zatytułowanym Statystyka chirurgiczna oficerów i generałów kontuzjowanych na różnych polach bitew $w$ zestawieniu alfabetycznym ${ }^{87}$ można znaleźć postaci, którym spieszył on z pomocą po tego rodzaju urazach, a wśród nich wspomnianego już generała Charlesa Moranda oraz marszałka Joachima Murata, rannego w twarz w Egipcie. Kula trafiła w szyję i przebiła policzek w prawym kącie żuchwy, na szczęście nie uszkadzając większych naczyń krwionośnych, i po opatrzeniu rany pacjent szybko wrócił do zdrowia, a na twarzy pozostał względnie niewielki ślad.

\footnotetext{
${ }^{83}$ Tamże, s. 105-117.

${ }^{84}$ Tamże, s. 93.

${ }^{85}$ Dictionnaire des sciences médicales, t. 29 (LON-MACH), Paris 1818, s. 375-440.

${ }^{86}$ D.J. Larrey, Relation médicale de..., dz. cyt.

87 Tamże, s. 372.
} 
Warto w tym miejscu zaznaczyć, co znów pozostaje w sprzeczności z opinią, że Larrey zajmował się przede wszystkim generalicją i wyższymi oficerami ${ }^{88}$, iż pod opisem zamieszczona została notatka o podobnym przypadku, który również operował. Był to szeregowy żołnierz z 32 demi-brigade o nazwisku Michel, z podobnymi obrażeniami, który „po pięciu miesiącach wrócił do zdrowia”89.

Jak widać, temat tych skomplikowanych obrażeń nie był obcy Dominikowi Jeanowi Larreyowi. Zajmował się zagadnieniem przede wszystkim od strony praktycznej, ale nie szczędził też uwagi problemom teoretycznym, wykazując, jak zawsze, szczególną wrażliwość sytuacyjną. Z całą pewnością bliskie by mu były słowa, że „każdy lekarz musi być przygotowany na to [...], iż może się spotkać z takimi obrażeniami twarzoczaszki, które nie są opisane w żadnym podręczniku"90.

\section{Bibliografia}

Allégret M., Morand Charles Antoine Louis Alexis (1771-1835), général, comte d'Empire, „Revue du souvenir napoléonien”, décembre 2005-janvier 2006, $\mathrm{nr} 462$.

„Alexandri Benedicti physici Anatomice sive historia corporis humani euisdem collectiones medicinales seu aforismi" in Officina Henrici Stephani, Parisiis 1514.

A. L., Notice biographique sur la vie et sur les travaux de M. le Baron Larrey, Paris 1841.

Benoît J., La bataille de la Moskova par le général baron Lejeune, „Revue du Souvenir Napoléonien” décembre 2004, nr 455-6.

„Biblija Święta”, Londyn 1945.

Bielecki R., Encyklopedia wojen napoleońskich, Warszawa 2002.

Bourachot Ch., Les hommes de Napoléon-Témoignages (1805-1815),

Paris 2011.

Czerwiakowski R.J., Narzadu opatrzenia chirurgicznego, Część II $\$ 196-\$ 743$, w Krakowie 1816 roku.

Czerwiakowski R.J., Narzadu powszechnego opatrzenia chirurgicznego, w Krakowie $1816 \mathrm{Cz}$. IV.

Czerwiakowski R.J., Narzadu powszechnego opatrzenia chirurgicznego część VII tabele, przez Rafała Józefa Czerwiakowskiego, Kraków 1817.

${ }^{88}$ W. Stembrowicz, D. Larrey, Fragmenty pamiętników dotyczace kampanii rosyjskiej, cz. I, „Medycyna - Dydaktyka - Wychowanie”, XXVII (1995), n. 1-2, s. 100.

${ }^{89}$ D.J. Larrey, Relation médicale de..., dz. cyt., s. 372.

${ }^{90}$ T. Korzon, Urazy szczęk i twarzy, Warszawa 1975, s. 19. 
Dictionnaire des sciences médicales, Paris 1818, T. 29 (LON $\mathrm{MACH})$.

Dziekońska I., Kara, Warszawa 1963.

Ferret-Dussart K., La chirurgie maxillo-faciale à travers l'histoire, Paris 2004.

Gasparis Taliacotii ... De curtorum chirurgia per insitionem, libri duo: in quibus ea omnia, quae ad huius chirurgiae, narium scilicet, aurium, ac labiorum per insitionem restaurandorum cum thoricen, tum practicen pertinere videbantur, clarissima methodo cumulatissimè declarantur ; additis cutis traducis instrumentorum omnium, atque deligationum iconibus, \& tabulis. Cum indice quadruplici expeditissimo, capitum singulorum, authorum, controuersiarum, rerum denique \& verborum memorabilium, Ad Gasparem Bindonium Juniorem, Venetiis, 1597.

Godart J., Quelques notes inedites du Baron Larrey, „Le Progres Medical", nr 9-10 (20 Mars 1940).

Grzelak E. (red.), Chirurgia praktyczna Rafała Józefa Czerwiakowskiego, Warszawa 1969.

Hamilton D., A History of Organ Transplantation: Ancient Legends to Modern Practice, Pittsburgh 2012.

Korzon T., Urazy szczęk i twarzy, Warszawa 1975.

Larrey D.J., Clinique chirurgicale, exercée particulièrement dans les camps et les hôpitaux militaires, depuis 1792 jusqu'en 1829, t. I, II, III, Paris 1829, t. IV, Paris 1832, t. V, Paris 1836.

Larrey D.J., Clinique chirurgicale, exercée particulièrement dans les camps et les hôpitaux militaires, depuis 1792 jusqu'en 1829. Atlas du tome cinquieme, br. m. i r. wyd.

Larrey D.J., Memoires de chirurgie et de campagnes, t. I-III, Paris 1812.

Larrey D.J., Memoires de chirurgie militaire et campagnes, t. IV, Paris 1817.

Larrey D.J., Memoires et campagnes, Wydanie krytyczne, Paris 2004.

Larrey D.J., Recueil de memoires de chirurgie, Paris 1821.

Larrey D.J., Relation médicale de campagnes et voyages de 1815 à 1840, Paris 1841.

Long F.X., Les blessés de la face durant la Grande Guerre. Les origines de la chirurgie maxillo-faciale, „Hist. des Sciences Medic.” 2002, t. XXXVI, nr 2.

Marchioni J., Place a monsieur Larrey, Arles 2006.

Płaczkowski W., Pamiętniki porucznika dawnej gwardii cesarsko-francuskiej spisane w roku 1845, Żytomierz 1861. 
Relation historique et chirurgicale de l'expedition de l'armee d'Orient en Egypte et en Syrie par D. J. Larrey, Paris l.An XI (1803).

Riaud X., Chirurgie maxillo-faciale et Grande Armée, „, e-mémoires de l'Académie Nationale de Chirurgie" 2016, nr 15(4).

Riaud X., Maxillofacial Surgery and Napoleonic Great Army, „Oral Health Care" 2018, vol. 3(2).

Richardson R.D., Larrey: Surgeon to Napoleon's Imperial Guard, London 1974.

Rochard J., Histoire de la chirurgie francaise au xixe siècle : Etude historique et critique sur les progres faits en chirurgie et dans les sciences qui s'y rapportent, depuis las suppression de l'Academie royale de chirurgie jusqu'a l'époque actuelle, Paris 1875.

de Saint-Hilaire M., Historia Napoleona, Gdańsk, 2004.

Saraf S., Parihar R., Sushruta: The first Plastic Surgeon in 600 B.C., „The Internet Journal of Plastic Surgery” 2006, vol. 4, nr 2.

Shen J.T., Weinstein M., Ambroise Pare (1510 to 1590): A Surgeon Centuries Ahead of His Time, „The American Surgeon”, June 2014, nr 80.

Singh V., Sushruta: The father of surgery, „National Journ. of Maxillofac Surg” 2017, Jan-Jun, nr 8(1).

Stembrowicz W., D. Larrey, Fragmenty pamiętników dotyczace kampanii rosyjskiej, cz. I, w „Medycyna - Dydaktyka - Wychowanie” 1995, t. XXVII, nr 1-2.

Tessier P., Chirurgie réparatrice et morphologique du nez, „Revue du Practicien” 1958, Oct, nr 21, 8(27).

Tessier P., Rhinoplastie post-traumatique et rhinopoïèse, „Gaz Med Fr.” 1966 Fevrier, nr 10, 73(3).

Turos M.J., Dominique Jean Larrey (1766-1842), Oświęcim 2017.

Znosko A., Mały słownik wyrazów starocerkiewnosłowiańskich i terminologii cerkiewno-liturgicznej, Warszawa 1983.

\section{Strony internetowe}

Mackiewicz M., Średniowieczna ręczna broń palna, http://www.muzeumwp.pl/emwpaedia/sredniowieczna-reczna-bron-palna.php.

Réunion des Musées Nationaux, Grand Palais (Château de Versailles). 